\title{
Consensual Unions in Burkina Faso: Trends and Determinants
}

\section{Thomas K. LeGrand}

Département de démographie

Université de Montréal (Canada)

CP 6128, succ. Centre-ville,

Montréal, Qc. H3C 3J7 Canada

tk.legrand@umontreal.ca

\section{Zourkaleini Younoussi}

Institut supérieur des sciences de la population

Université de Ouagadougou (Burkina Faso)

\begin{abstract}
This paper examines entry into consensual unions versus marriages in Burkina Faso, a topic that has received little attention to date in sub-Saharan Africa. Changes in marriage behaviors may entail or reflect profound changes in family organization, gender relations and fertility and, to the extent that consensual unions are relatively transitory and lead to more sexual partners, they may be associated with greater sexual risks including HIV. The determinants of new unions being consensual are estimated from national family-life type survey data that provide information on the timing of different types of marriages and the start of cohabitation. While consensual unions are not new to the country, they appear to be changing in nature and have been growing more common over time especially in urban areas. They are also more popular among men and women with greater schooling or who began cohabiting while living outside the country, and for women who have previously lived in union.
\end{abstract}

Key Words: Consensual unions, common-law unions, mutual consent unions, cohabitation, marriage, union type, polygamy, family, Burkina Faso, Sahel, subSaharan Africa, Africa. 


\section{Résumé}

Cet article compare les entrées en unions libres avec et les mariages au Burkina Faso, un sujet ayant reçu peu d'attention en Afrique sub-saharienne jusqu'à présent. Les changements de comportements reliés au mariage peuvent impliquer ou refléter de profondes modifications dans l'organisation des familles, dans les relations entre les sexes et dans la fécondité. Si les unions libres sont en général plus transitoires que le mariage et entraînent un plus grand nombre de partenaires sexuels, elles peuvent être associées à une hausse de pratiques sexuelles à risque pouvant mener aux infections du VIH. Les déterminants de type d'union (libre ou mariage) ont été estimés en utilisant les données d'une enquête nationale de type biographique à l'aide d'information sur la chronologie des différents types de mariage et les débuts de cohabitation. Bien que les unions libres ne soient pas un nouveau phénomène au Burkina Faso, il semble que leur nature s'évolue sur le temps et qu'elle! s soient de plus en plus courantes, particulièrement en ville. Elles sont aussi plus répandues chez les hommes et les femmes ayant un niveau d'éducation plus élevé ou ayant commencé leur union alors qu'ils résidaient hors du pays, ainsi que chez les femmes ayant déjà vécu en union.

Mot clés: unions libres, unions consensuelles, cohabitation, mariage, type d'union, polygamie, famille Burkina Faso, Sahel, Afrique sub-saharienne, Afrique.

\section{Introduction}

This paper uses detailed retrospective data from Burkina Faso to examine entry into consensual unions (also called mutual consent or common-law unions) versus marriages, a topic that has received little attention to date in sub-Saharan Africa. The analysis aims to document patterns of change over time and to assess the effects of possible determinants on the likelihood of a new union being consensual - in particular, the influence of "modernization" variables such as schooling attainment or urban residence on union type. 


\section{Context and Literature Review}

Compared to much of Eastern and Southern Africa, Burkina Faso and the other Sahelian countries of West Africa are characterized by earlier women's ages at first marriage, low rates of permanent celibacy, high levels of fertility within marriage and relatively few consensual unions. Families in the Sahel continue to play important roles in guiding the marriage behaviors of young men and women, especially for first unions. In Burkina Faso, several different types of marriages and wedding ceremonies coexist and overlap. By far the least common are civil marriages performed by an officer of the state, and the laws governing marriage are little known or respected in either rural or urban areas. ${ }^{1}$ Two other types of marriage prevail: religious marriages sanctified by a celebration in a mosque or church, and traditional marriages in which a woman joins her future husband once a certain number of ritual ceremonies have been conducted among her relatives. Each of these types of marriage constitutes the starting point for a new family and, often for the young woman, the beginning of socially accepted sexual relations (Kaufmann and Meekers, 1988; Antoine, 2000a; Marcoux et al., 1995). None of them can be formally ruptured without community acknowledgement.

Consensual unions, which we define as cohabitating unions in the absence of a wedding ceremony, are not new to Burkina Faso. A 1969 survey of several urban and rural areas in the country showed that consensual unions accounted from five to ten percent of ongoing unions at that time (Pool, 1977). Premarital sexual relations that sometimes take the form of consensual unions were common in the traditions of several of the smaller ethnic groups in the country. For example, the Samo and Goin had matrimonial systems are characterized by "double unions": premarital liaisons occurring first between lovers, followed by a marriage arranged by the two families; lover and spouse oftentimes being distinct (Lallemand, 1981; de Rouville, 1987; Dacher, 1993; Fiéloux, 1993; Thiriat, 1999). Along the same lines, young Dagara and Lobi women were expected to prove their fertility through childbirth prior to marriage, and cohabitation with their prospective spouse was permitted, as were sexual liaisons with other lovers up until the time of first childbirth (e.g., de Rouville, 1987). These practices are thought to be disappearing and premarital sexual relationships have become less socially acceptable, although possibly more frequent, in modern times.

A sort of eloping (called enlevement in French) is also well known in past and present-day Burkina Faso. ${ }^{2}$ This happens when a young couple seeks to get married against the wishes of the woman's family: typically, the woman runs away to be hidden by the man's relatives where she remains until they are able to convince her parents to agree to compensation and acknowledge their union. In general, the woman's family is most amenable to accepting their union (and thereafter allow a wedding to occur) once the young couple starts having 
children. When they refuse, the couple may choose to continue living together rather than separate. Lastly, today as in the past, older men and women have much more freedom to establish subsequent unions on their own, and extensive celebrations and the payment of bride wealth are less common for them (Antoine and Nanitelamio, 1991; see also Pool, 1977). Generally speaking, these unions are socially accepted even in the absence of a wedding.

Changes in marital behaviors may entail or reflect profound changes in family organization, gender relations and fertility. Marriage patterns vary enormously across sub-Saharan Africa (van de Walle and Lardoux, 2005; van de Walle and Baker, 2004; Hertrich, 2001; NRC, 2005) and there is evidence of important changes in union behaviors from a variety of contexts. These include a growing prevalence of consensual unions, greater power for young men and women to choose their partners, rising ages at first marriage especially for women, and, in some parts of the region, increasing proportions of men and women who remain celibate - never married nor lived in union (NRC, 2005, ch. 7; Mensch et al., 2005; Hertrich, 2001; van de Walle and Baker, 2004; Meekers, 1992; Antoine and Nanitelamio, 1991). The HIV/AIDS pandemic has further heightened the policy importance of issues related to sexual relations in Africa in recent years. Consensual unions, to extent that they may be more transitory and lead to greater numbers of sexual partners, can potentially facilitate spread of sexually transmitted diseases, and this has served to increase interest in the topic.

In much of Africa, consensual unions are thought to occur mostly in cities, where new behaviors are being experimented with, the processes of individualism are more pronounced, and the effects of the economic recession have been felt most acutely (Meekers, 1992; Adepoju, 1997; Thiriat, 1999; van de Walle and Baker, 2004; van de Walle and Lardoux, 2005; Pool, 1977; Coulibaly and Pool, 1975; Pool, 1968). Cities are characterized by higher levels of schooling, a mix of ethnic groups with different norms and traditions, and a greater influence of foreign ideas through the media. Young urban adults should generally be less constrained by social controls; this is particularly true for those who migrated to cities for jobs or schooling, leaving their families behind (Mondain 2004; van de Walle and Baker 2004). In addition, a severe economic crisis has affected the region since the 1970s. Research on urban Burkina Faso, Bamako and Dakar has shown that growth in men's age at marriage is associated with their increased difficulty to obtain acceptable jobs and move out of the family home, often prerequisites for marriage and starting a family (Calvès, 2007; Calvès et al., 2007; Antoine and Djiré, 1998; Antoine et al., 1995; Marcoux and Piché ,1998).

The often high costs of marriage ceremonies and bride wealth have increasingly become the responsibility of young men rather than their families. In this situation, the costly marriage rituals and celebrations may be delayed or spaced out (Calvès et al., 2007; Marcoux et al., 1995; see also Attané, 2003; 
Cooper, 1995; Locoh, 2000; Boye et al., 1991). There may also be a growing tolerance to cohabitation as a prelude to, or even as a substitute for, marriage (NRC, 2005, ch. 7; see also Meekers, 1992). Some women may view consensual unions as alternatives to marriage that offer more independence: a greater say in partner choice, more control over their subsequent lives, and better protection of their rights over children. ${ }^{3}$ Marriage in Burkina Faso usually confers to the husband paternity rights over children, including sometimes those already born to the mother (Dacher, 1992; de Rouville, 1987; see van de Walle and Lardoux, 2005 for nearby Mali, and Pool, 1968 for Ghana). Elsewhere in Africa, some young educated women have been observed to prefer the freedom of being an "outside wife", living in a consensual union in a separate residence from the "inside" married wife (Wa Karanja, 1994; Thiriat, 1999; see also Antoine and Nanitelamio, 1990; Calvès and Meekers, 1999).

\section{Data}

Data are from the 2000 Survey on migration, urban integration and environment in Burkina Faso (SMUIE/BF). ${ }^{4}$ This is a family life-type survey providing detailed nationally representative retrospective data on 4,075 men and 4,570 women aged 15-64 at the time of the survey, living in 3,517 households; see Poirier et al. (2001) for details. Urban residents and respondents aged 25-64 were over-sampled to ensure their adequate representation in the data. For this study, consensual unions are defined as cohabiting unions in the absence of any traditional, religious or civil marriage ceremony.

\section{Measurement issues concerning marriage and consensual unions}

Marriage is not simple to measure in sub-Saharan Africa, as it often involves a long process that differs across ethnic groups and religions, rather than a single event occurring at point in time (van de Walle, 1993; Bledsoe and Pison, 1994; Thiriat, 1998, ch. 5; Antoine, 2000b; van de Walle and Lardoux, 2005). As a result, the usual survey and census questions that ask men and women for their marital status can give rise to subjective answers that can vary over time and across societies (van de Walle, 1993). Inaccuracies should be more pronounced for retrospective reports of past behaviors than for current status, in part because people may ex post reassess their lives. For instance, unions that succeed may be reported as having been marriages early on in the process, while shorter-lived unions that did not come to fruition may not be declared at all. Too, as cohabitation in the absence of marriage is often considered shameful in the Sahel, some respondents may choose to misrepresent their situation in order to appear more respectable: stating that they are married when they are not. 
Underreporting of consensual unions may be especially severe for polygynous men when surveys and census questions focus on their marital status rather than on the nature of the relationship with each of their partners. For example, some men may be both married to one woman and in a non-marital union with another - the "outside wife". Given typical questionnaire design, they would probably report being married with two spouses, and we would not know that one of their unions is consensual. This is not a problem for women, who are usually in at most one union at a time.

For a retrospective survey, the SMUIE/BF is well designed for the study of union behaviors. In contrast to most other surveys, it used the event history calendar method to collect data from both men and women on a series of major events occurring in their lives, including the month and year of the main religious, civil and traditional wedding ceremonies (if any), and also the start of cohabitation, for each of their unions. The event history calendar method is known to be relatively accurate for collecting data on the timing and especially sequences of past events such as cohabitation and wedding ceremonies - data central to our study (Freedman et al., 1988; Panel Study of Income Dynamics, 2005). Unlike marital status, wedding ceremonies are usually well-recognized events that are less subject to interpretation. Christian and civil weddings and their celebrations are expensive events that take place toward the end of the marriage process. Muslim marriages may entail more stages and ceremonies, although in general we expect that their weddings will also be declared at the end of the process when a major marriage ceremony takes place. ${ }^{5}$ Traditional marriages are harder to characterize and some ethnic groups have several ceremonies that occur over time. For these, we believe it likely that most respondents will report the date when the man's family first sent a delegation to the woman's home to formally propose a marriage alliance.

From our knowledge of present-day Burkina society, regular cohabitation before any of the weddings described above would not be socially accepted nor approved by families, at least for first unions. In other words, given the reporting of wedding ceremonies in our data, it is unlikely that many of the unions we define as "consensual" are, in fact, socially recognized marriages captured early on in the regular marriage process. When consensual unions are afterwards formalized by a wedding, it is probable that a decision was made to proceed onto marriage: the couple decided to formalize their union, the man succeeded in drawing together the funds to pay for the bridewealth and wedding costs, or the family begrudgingly accepted a marriage rather than tolerate an ongoing consensual union.

Table 1 shows the prevalence of consensual unions in Burkina Faso at the time of data collection measured by recent national surveys and the 1996 Census. According to the arguments presented above, SMUIE/BF data should provide more accurate estimates of the frequency of consensual unions, especially for men. With the exception of women interviewed by the 2003 
Demographic and Health Survey (DHS), the SMUIE/BF does appear to capture many more consensual unions than the other data sources, with differences being larger for men. Interestingly, DHS data show a substantial increase in the prevalence of consensual unions between 1998-99 and 2003, including for women for whom the relevant survey questions were largely unchanged (this was not the case for men), suggesting that this type of union has become more common in recent years.

\section{Research Goals and Hypotheses}

Given the general lack of solid statistical studies on consensual unions in subSaharan Africa, a first objective of this study is to document patterns of type of union and change over time. In addition, the multivariate analysis is guided by the following hypotheses:

- Observed increases in the incidence of new consensual unions over time should be concentrated in urban areas.

- Consensual unions should be more common among people who are relatively "modern": those with higher schooling attainment or living in urban areas, where the context is more conducive to the establishment of consensual unions.

- Unions that are more likely to have occurred without family approval should be more often consensual: those begun abroad or with partners from different ethnic groups.

- Second and higher-order unions should be more often consensual, given the greater freedom accorded to men and women who were previously married.

\section{Method}

Logit regressions are used to assess the determinants of a newly formed cohabiting union (including both first and subsequent unions) being consensual rather than a marriage over roughly the 1960 to 2000 period. Because some consensual unions may be transitory, others may occur as part of a marriage strategy and a few may conceivably be marriages captured early on in the marriage process (prior to the reported wedding), we examine union type at the start of cohabitation both for the set of all unions observed in the data and also for the subset of "longer-lasting unions". Longer-lasting unions are those known 


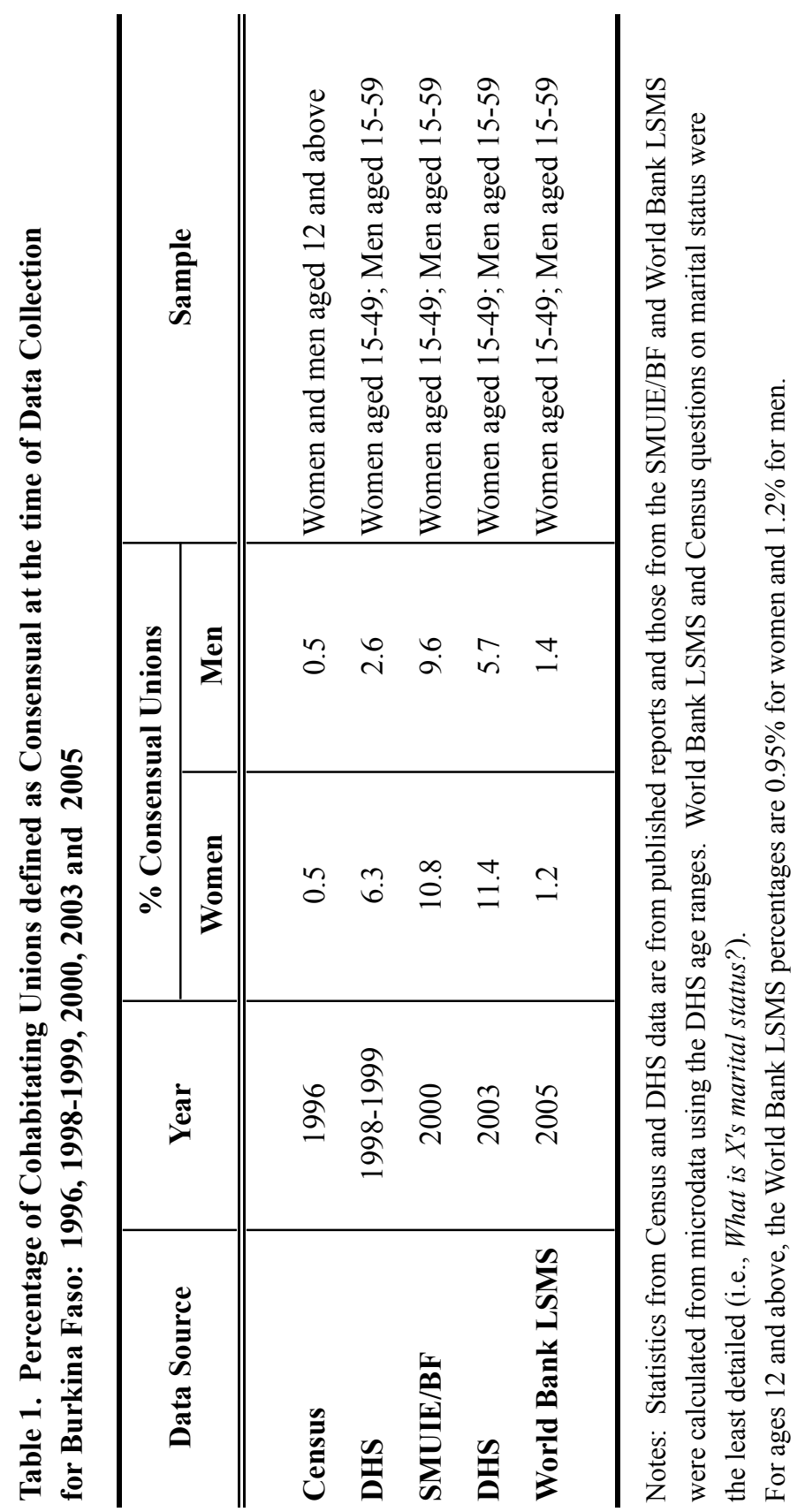

CSP 2009, 36.3-4: 267-294 
to last for at least three years; for them, consensual unions that were transformed into marriages by a wedding over the three-year period following the start of cohabitation are redefined as marriages, and consensual unions and marriages that end over the interval are omitted from the analysis. Compared to the full set of unions captured at the start of cohabitation, the subset of longer-lasting unions should better reflect long-term lifestyle choices. It may also be the case that respondents underreport short-lived unions occurring in the past, of which many may be consensual. If true, this would act to bias estimates of time trends, leading to an overestimation of the extent of increases in consensual unions over time (see the discussions in van de Walle, 1993 and Thiriat, 1998). An assessment of trends based on unions lasting at least three years should be less sensitive to this type of measurement error.

The regressions are estimated using sample weights to study the likelihood of a cohabitating union being consensual, measured at the start of cohabitation both for all new unions and for longer-lasting unions. As the questionnaire measured time in one-month increments, new unions are counted as marriages if a wedding ceremony was declared to occur prior to or during the same month as the start of cohabitation. Separate regressions are estimated for men and women, whose marital strategies and behaviors are known to differ. ${ }^{6}$ Cluster controls provided by Stata are used to handle cases of multiple unions occurring to individuals (polygamous unions for men, and subsequent unions after separation, divorce or widowhood for both men and women) and robust significance levels are shown in the tables. All covariates are measured retrospectively, reflecting the situation that existed at the time of first cohabitation for each union. They are: time period, place of residence, the person's age group, level of schooling, ethnic group, religion, whether the union is their first union, whether a child was born before the start of the union (data available only for women) and, for partners, marital status at the start of the union and whether they belong to a different ethnic group.

\section{Empirical Results}

The status of unions three years after the start of cohabitation is shown in Table 2 , based on the subset of unions that began at least three years prior to the survey. About two-thirds of consensual unions in this subset were ongoing and still consensual 36 months later; these are the "longer-lasting" consensual unions used in the regressions, below. Marriage was by far the main cause for the disappearance of roughly one-third of consensual unions: between $24 \%-40 \%$ of men's and $23 \%-30 \%$ of women's consensual unions were followed by a wedding ceremony over the three year interval. This drop in their number was concentrated in the first 12-18 months; Kaplan Meier survival curves show that 


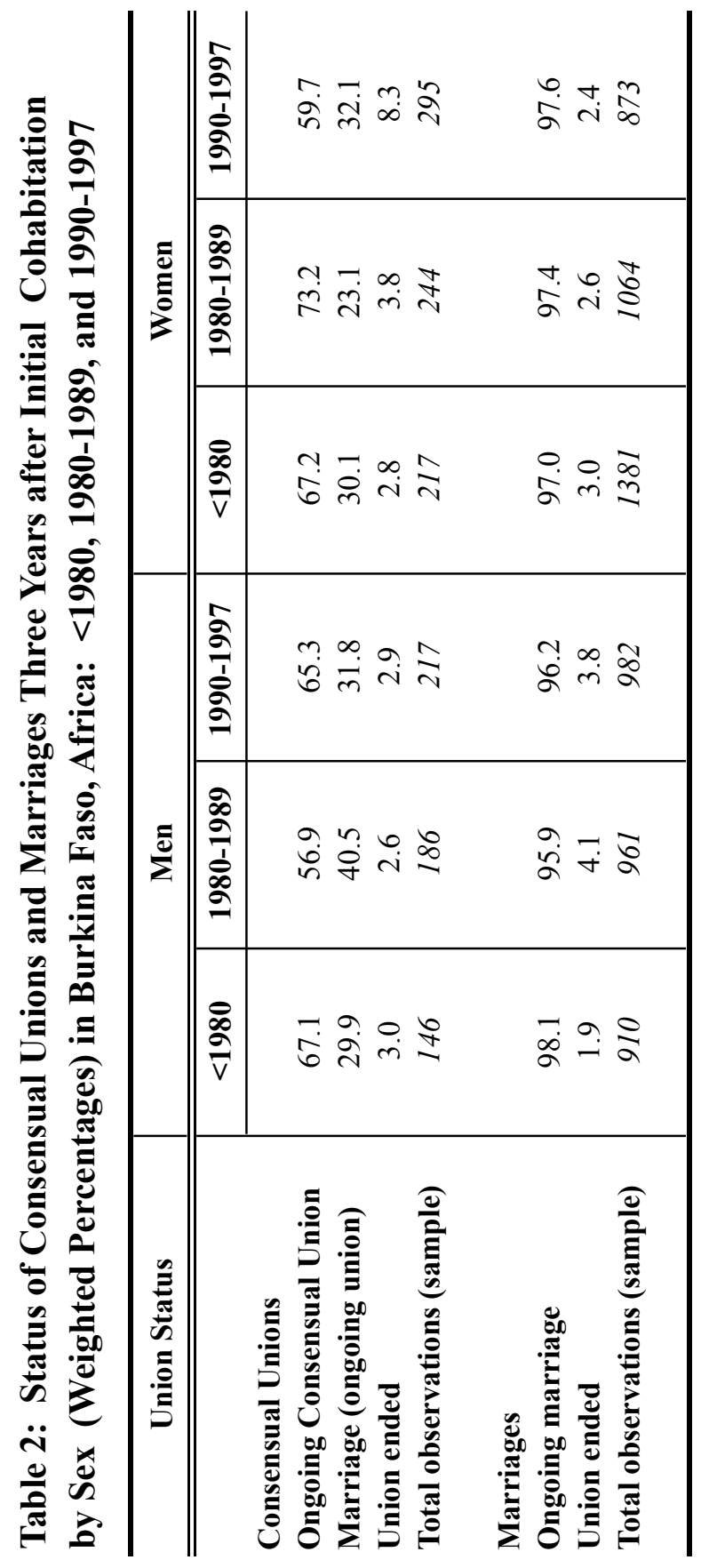


the subsequent decline was much more moderate and slowly tended to level off. ${ }^{7}$ Anecdotal evidence suggests that, at least in the cities where unemployment and school are acting to delay marriages, consensual unions are often formalized after the first child is born, a year or two after their establishment. However, there is no clear evidence in the data of an upward trend in consensual unions being transformed into marriages over time. Such a trend might occur, for example, if consensual unions were increasingly motivated by young men's need for more time to amass the resources in recent years, required to pay the heavy costs for wedding ceremonies and bridewealth; the lack of resources impeding weddings but not necessarily cohabitation for a willing couple. While it is surely the case that some young people's decisions to enter consensual unions are motivated by the high costs of marriage, it does not appear that such unions are afterwards being disproportionately transformed into marriages - at least not more now than in the past.

Ruptures are uncommon for both consensual unions and marriages. ${ }^{8}$ For men, only $2 \%$ to $4 \%$ of reported consensual unions and marriages ended within three years, depending on the time period under consideration. (This does not include consensual unions that were transformed into marriages, which is not union dissolution per se.) For women, consensual unions that started before 1990 were also almost as stable as marriages; this seems to have changed somewhat in the most recent time period under study (1990-97), when $8 \%$ of their newly begun consensual unions ended within 36 months.

The finding that consensual unions are nearly as stable as marriages surprised us. Insofar as consensual unions entail a couple living together without community acknowledgement, they should be less binding: the couple is primarily responsible for its future, facilitating separations in the event of disaccord. Marriages, which usually involve negotiations between families, the payment of bridewealth and expensive celebrations, should be harder to dissolve. Some unions are consensual simply because they go against the desires of one or both families, making it difficult to obtain family approval for marriage. In such cases, continued family pressures may be exerted to try to force a separation. For all of these reasons, we had expected consensual unions to be less stable than marriages.

The high level of stability of consensual unions in the data suggests that they are not a serious problem in terms of risky sexual behaviors, which would have occurred if breakups were frequent, leading to a succession of sexual partners that could facilitate the spread of HIV and other STIs. It should be emphasized, however, that very short-lived unions are probably underreported by both men and women in the data, and the survey did not collect information on sexual relationships occurring without cohabitation - relationships that may entail higher reproductive health risks. 


\section{Time Trends and Place of Residence}

Table 3 shows summary statistics for the variables used in the analysis and Table 4 presents the logit regression results for the probability of a new union being consensual for men and women, and for both all new cohabitating unions and the subset of longer-lasting unions. Two regression models are estimated for each group: the first one limited to the time period and place of residence variables, and the second one with the full set of covariates. As SMUIE/BF data were collected from a sample of people aged 15-64 in 2000 and who were, thus, at most 35 years old in 1970, the estimated time trends are driven in large part by changes in the behaviors of relatively younger men and women about whom we have more information in the past. This should not greatly affect our findings, as most marriages in Burkina Faso occur fairly early in adult life. In the data, women's median age at the start of a first cohabitating union was 17 years; for men it was 25 .

The results confirm that consensual unions are not a recent phenomenon in Burkina Faso: roughly 16\% of all new unions and 9\% of new longer-lasting unions that began before 1980 were reported as consensual at the start of initial cohabitation (Table 3). The likelihood of a new union being consensual rose over the following two decades for both men and women. This trend is equally visible for all new unions and also for longer-lasting unions, indicating that the observed growing importance of consensual unions is not due to an underreporting of transitory consensual unions occurring in the past - a problem that should not much affect the statistics on longer-lasting unions. In the 1990s, about $22 \%$ of women's new unions and $19 \%$ of those for men were estimated to be consensual; for unions that lasted at least three years, about $14 \%$ of new unions were declared as consensual by both sexes. The growing importance of consensual unions is also clear in the odds ratios in Table 4, including those estimated from the model 2 regressions that control for the socioeconomic and demographic covariates.

Among men and women living in Burkina Faso at the time of union formation, consensual unions appear to be most popular in Ouagadougou, with the one exception being women's longer-lasting unions, for whom consensual unions were more common in the other urban areas. For the most part, the estimated urban/rural differences are statistically insignificant.

As hypothesized, the highest proportions of consensual new unions are observed to occur to those residing outside of Burkina Faso at the start of the union and who returned to the country by the time of the survey - often labor migrants to Cote d'Ivoire (Cordell et al., 1998; Beauchemin et al., 2007; see also Courel and Pool, 1975). There are a number of possible reasons for this finding. First, while abroad, young men and women should generally enjoy greater social freedom due to their distance from their families, and interactions 


\begin{tabular}{|c|c|c|c|c|c|}
\hline 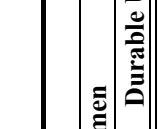 & 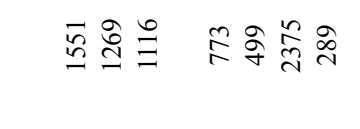 & 产 & 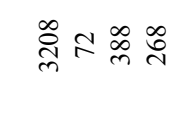 & 悹导 & 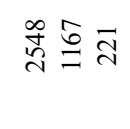 \\
\hline 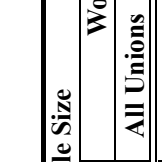 & 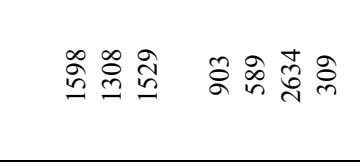 & 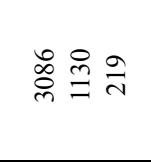 & 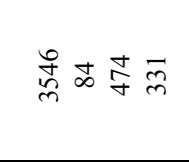 & 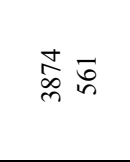 & 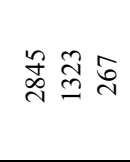 \\
\hline 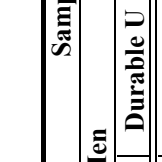 & 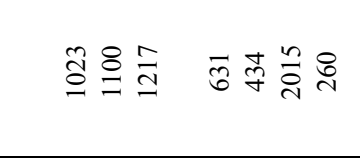 & 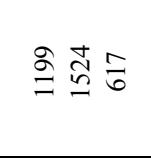 & 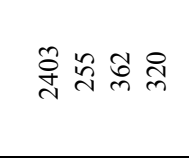 & 号志 & 拿: 品 \\
\hline 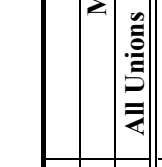 & 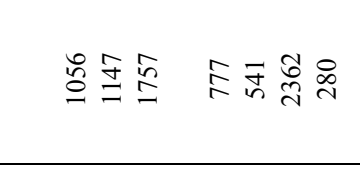 & F & 喜兽等导 & 总䓵 & 尊: \\
\hline 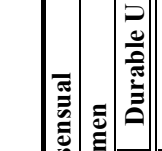 & 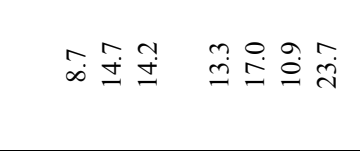 & $\stackrel{\circ}{=}=\dot{0}$ & 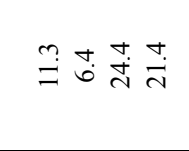 & ำ & 过声 \\
\hline 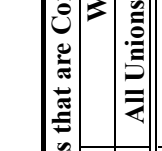 & 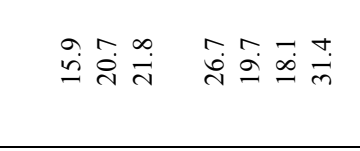 & 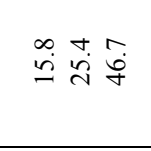 & 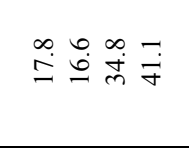 & 量寺 & 象号 \\
\hline 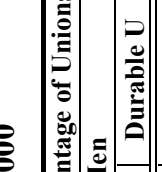 & 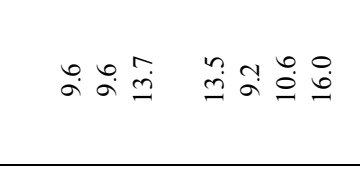 & $\stackrel{\infty}{=} \dot{2} \stackrel{9}{=}$ & 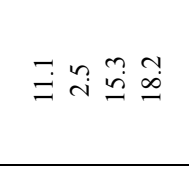 & $\stackrel{\infty}{\stackrel{\infty}{=}}=$ & $2: 3$ \\
\hline 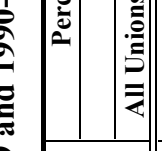 & 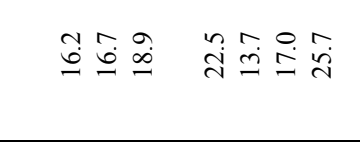 & 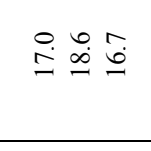 & 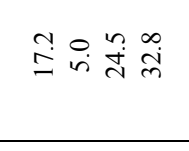 & $\underline{Z} \overline{\underline{\alpha}}$ & 旾: \\
\hline 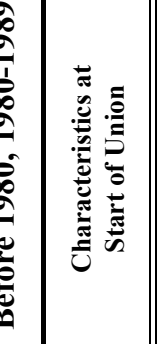 & 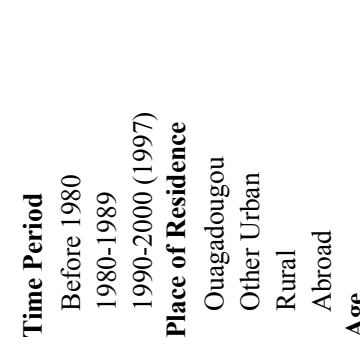 & & 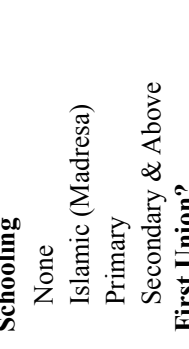 & 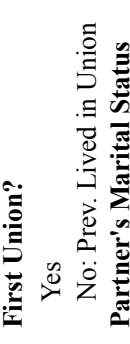 & 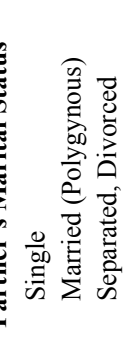 \\
\hline
\end{tabular}




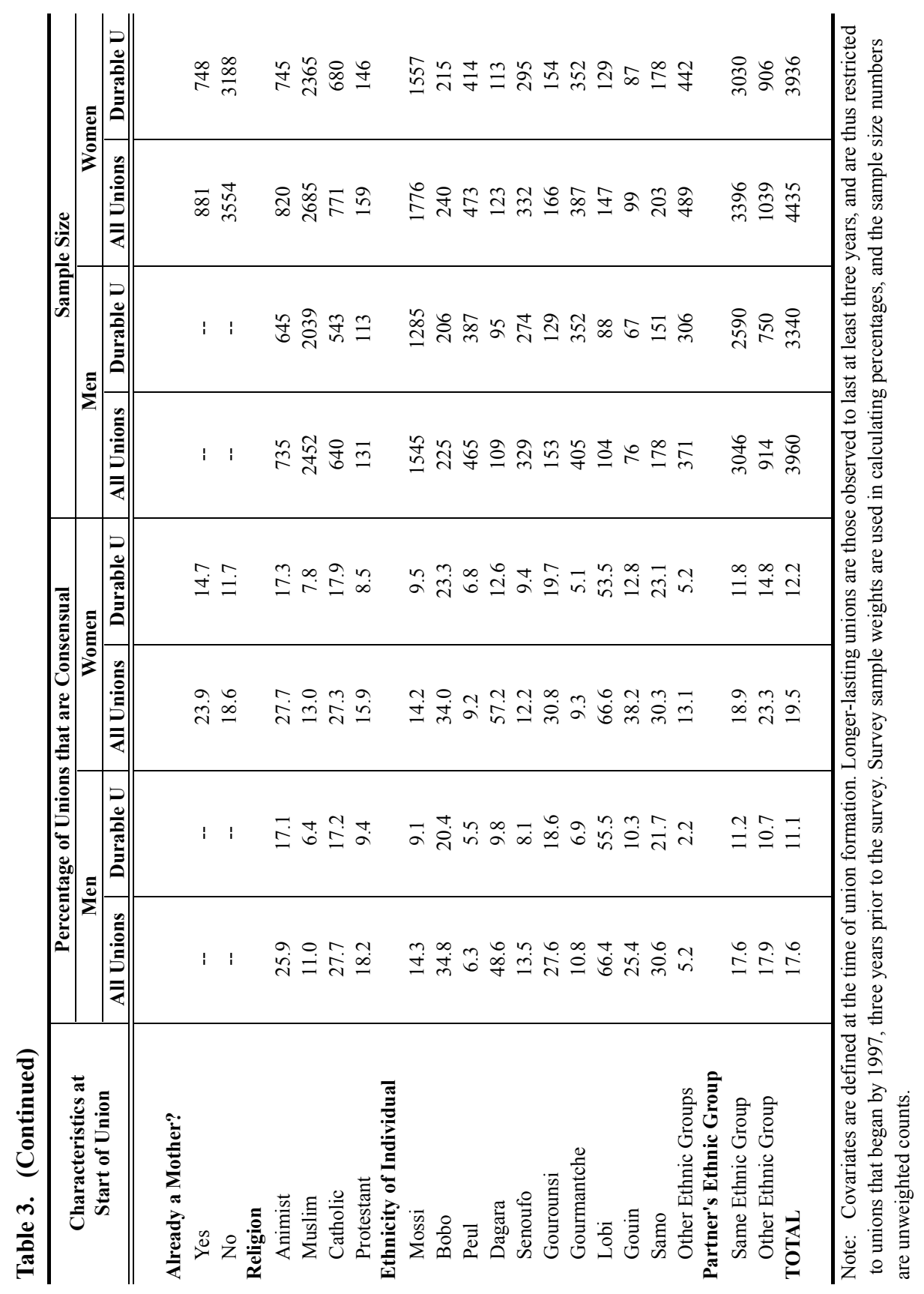


Consensual Unions in Burkina Faso: Trends and Determinants

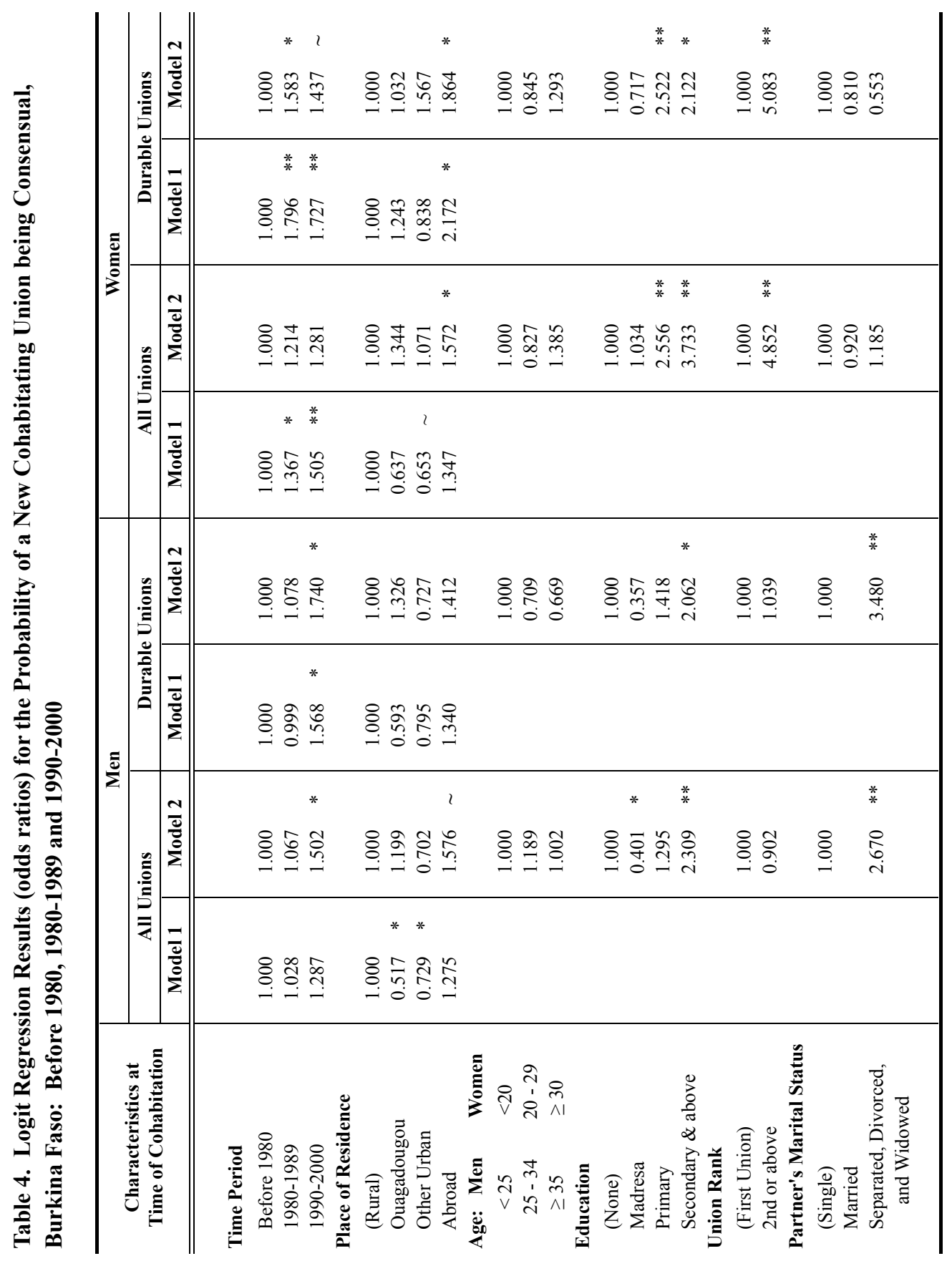




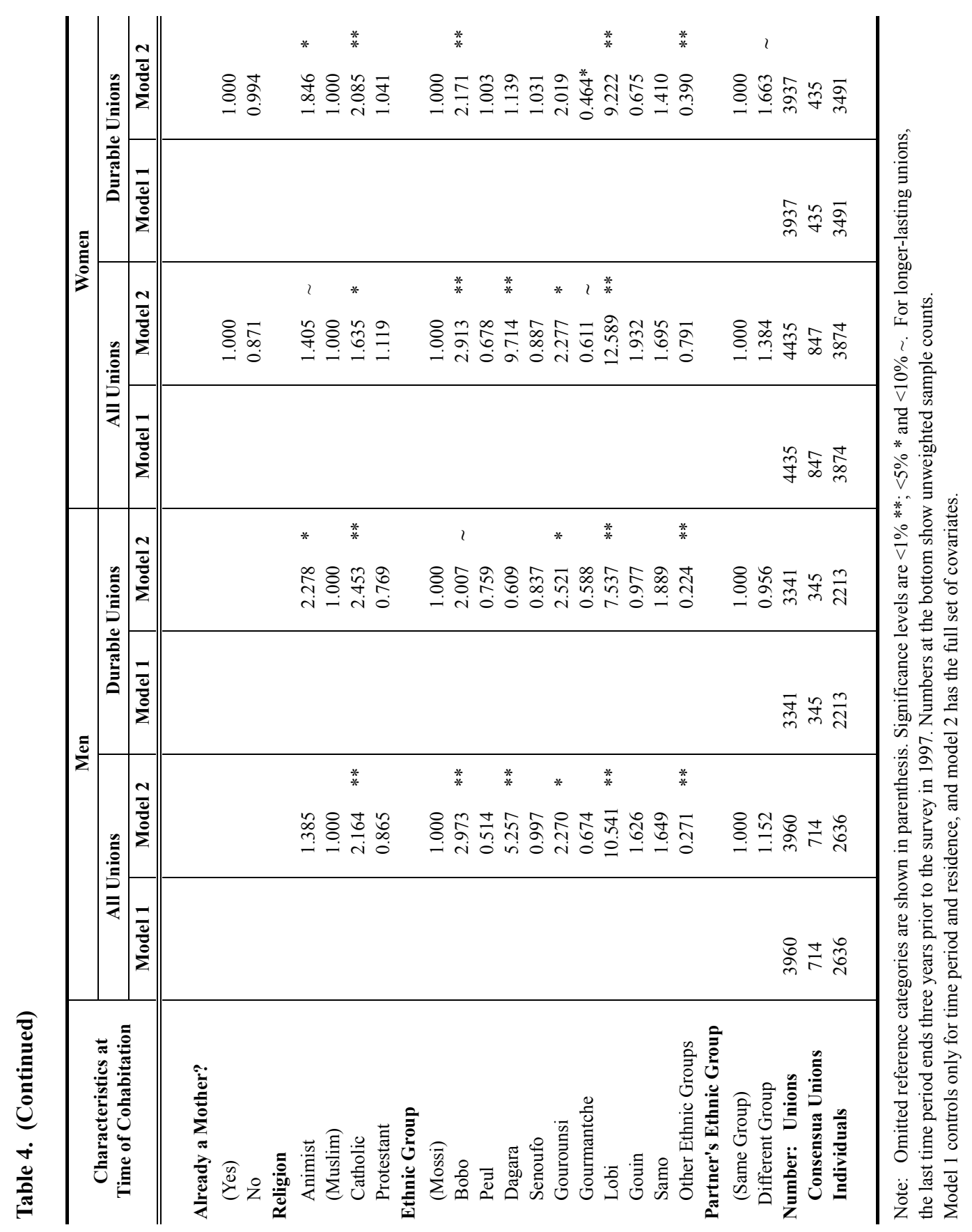


marriage behaviors. Statistics from the DHS are consistent with this argument, showing consensual unions to be considerably more popular in Cote d'Ivoire than in Burkina Faso: over 22\% of women's ongoing cohabiting unions enumerated by the 1998/99 survey were reported as consensual, a level roughly double that found for Burkina Faso in 2003 ((DHS StatCompiler, 2008; see also Table 1).

Along the same lines, it is plausible that, the longer the time spent living away from one's family, the greater the influence of these factors. Along these lines, Beauchemin et al. (2007) found that, as the period a migrant spends outside Burkina Faso lengthens, the likelihood that they will resettle in their home village after their return declines, suggesting that the influence of close family and kin lessens over time. In our data, some of the longer-term return migrants had permanently settled in Cote d'Ivoire, only to be forced to return to Burkina Faso in the 1990s due to the worsening political context. To the extent that these people had pulled up roots when they first emigrated, the influence of new attitudes and behaviors should be especially strong for them. To explore this idea, the model 2 regressions were re-estimated in which an additional migration variable was added to distinguish between short and longer-term $(>3$ year) stays abroad. The results support these arguments: as time spent outside the country increased so did the probability of a new union being consensual, with differences being large and statistically significant for women, and fairly small and insignificant for men.

Two other reasons may underlie the relation between return migrant status and consensual unions. First, migrant selectivity may cause those who are relatively more open to new experiences and ideas both to be more likely to migrate and also to engage in a consensual first union. Second, it is possible that, for some couples, planned weddings were postponed until the next trip home, meaning that their unions should be considered more as marriages with delayed wedding ceremonies rather than as consensual unions. This last reason is unlikely to be an important part of the explanation, as the same result is observed for marriages and consensual unions in our set of longer-lasting unions.

The time trends and spatial differences shown in Tables 3 and 4 may potentially reflect averages of quite different trends occurring in the urban and rural areas. To investigate this possibility, additional regressions were run with the time period and place of residence variables replaced by a full set of time by area interactions (for example, Ouagadougou before 1980) which allows for divergent trends in each area. The results show that, among those living in Burkina Faso at the time of union formation, change occurred most rapidly in urban areas. Prior to 1980 , new unions were considerably more likely to be consensual in rural areas than towns for both men and women - differences that are statistically significant compared to Ouagadougou for men, and compared to the other urban areas for women. Since then, consensual unions have grown 
more common in all areas, a change that is especially pronounced in towns and cities. For men, the odds of a new union being consensual grew tenfold ${ }^{9}$ in Ouagadougou while, in the rural and other urban areas of the country, the increase was always under 1.6 times and statistically insignificant. For women, the relative frequency of consensual unions also grew more rapidly in urban areas, although for them the estimated changes were largest in the other urban areas. ${ }^{10}$ By the 1990 s, new unions were more likely to be consensual in urban than rural areas, although areal differences were not significant.

\section{Demographic and Socioeconomic Factors}

The results show that school attainment affects type of union, as hypothesized. Women who attended regular schools at both the primary and secondary and above levels are significantly more likely to enter into a consensual union, compared to those with no schooling. Men who attended these schools are also more likely to enter into consensual unions, although for them the estimated effects are smaller and, for primary schooling, statistically insignificant.

Women's past union experiences have a very pronounced impact on the likelihood of a union occurring without the community sanction of a wedding ceremony, according to the Table 4 results. Marriages predominate women's first unions, while consensual unions are much more common in subsequent unions. For divorced, separated or widowed women, the odds of a new union being consensual is roughly five times that of women entering into their first unions for both the set of all new unions and for longer-lasting unions. This finding makes sense in the social context of Burkina Faso, where parents and the wider family continue to play important roles in overseeing children's first marriages. Women who had previously lived in union - mostly marriages - have much greater leeway in establishing subsequent unions on their own, and they may choose to forego the costly wedding celebrations. Interestingly, after controlling for women's prior union experience and other variables, the estimated effects of age, whether they had previously given birth, and the marital status of their partner at the start of their union are all insignificant.

In contrast to women, men's prior union experiences - their marital status at the start of the union - do not significantly affect the likelihood of a new union being consensual. It needs to be stressed, however, that union rank has a very different meaning for men and women in Burkina Faso, where polygyny is common. A large majority of men's second and subsequent unions in the data were polygynous and roughly three-fourths of men's second or higher-rank spouses were single up until the time of that union. In the local context, the families of these yet-unmarried women would almost invariably have insisted on formal marriages. In contrast, all of women's second and higher order unions could only have occurred after widowhood, separation or divorce. These women 
tended to be somewhat older and about two-thirds of their new partners were currently or had previously been married. The effect of women's union status prior to the start of cohabitation is again evident in the men's regressions: the odds of a man entering a consensual union is roughly three times higher when their new partners had previously lived in union, compared to those at their first union. As was the case for women, men's age has no significant effect on type of union after controlling for the effects of the other variables.

Religion and ethnicity Unlike ethnographic studies of union behaviors that examine the behaviors of particular groups in specific contexts, this study aims to assess the wider social determinants of union behaviors and change across the country, focusing on the hypotheses listed earlier. For that reason, the variables representing religion and ethnicity are not central to our analysis and are included mainly as control variables. These variables may nonetheless have important effects on type of union (e.g., Pool, 1977), as religions can vary in their degree of disapproval of consensual unions, and ethnicities can differ in terms of social norms, the degree of social control exerted by the older generation over young people's behaviors, the traditional marriage process, the importance placed on specific ceremonies, and perhaps even people's willingness to report short-lived consensual unions in their past.

The results show that religion affects union type, especially for longerlasting unions. For both men and women, Catholics and animists are more likely to enter into consensual unions than Muslims and Protestants. Muslim men who only attended a madersa (traditional Islamic school) are especially unlikely to enter a consensual union, although the estimated effect of this variable is significant in only one regression. Differences between the Catholics and Protestants may be due in part to the Catholic Church's opposition to divorce and remarriage, which could explain the recourse to consensual unions for subsequent unions by members of that religion.

The Bobo, Gourounsi and especially Lobi ethnic groups appear to be comparatively open to consensual unions. The small Dagara group stands out in the sense that both men and women of this group have high odds of entering into a consensual union in the "all unions" regressions, and roughly average odds in the "longer-lasting unions" regressions, indicating that they have a higher occurrence of transitory consensual unions than other ethnic groups. About twothirds of Dagara "consensual" unions captured in the data were followed by a wedding in the next three years, compared to somewhat over one-fourth for all other ethnic groups combined. The Lobi and Dagara ethnicities are atypical for Burkina Faso, and aspects of their cultures may underlie these results. Concentrated in the south of the country, their societies are matrilineal or both matrilineal and patrilineal, unlike most other ethnic groups, and they are viewed as being broadly similar (Goody, 1969: 169, 202). In their traditions, women are often expected to prove their fertility by childbirth before marriage; occasional premarital cohabitation with the prospective spouses is permitted, as are sexual 
liaisons with other lovers prior to the first birth (de Rouville, 1987). For both of these groups, the degree of social control exercised by the family over the sexual behaviors of youth is much weaker than that of most other ethnic groups in the country, including the dominant Mossi.

\section{Summary and Discussion}

We use detailed retrospective data to examine the determinants and changes over time of the relative frequency of consensual unions versus marriages in Burkina Faso. For the most part, the results support our initial hypotheses. New cohabitating unions are more likely to be consensual in situations where the influence of different norms and attitudes are comparatively greater and the importance of traditional social controls weaker - when partners are relatively better educated or when cohabitation began when they were living abroad. In addition, there is clear evidence of an increasing popularity of consensual unions over time, a finding that is significantly more pronounced in urban areas, as hypothesized. Unions made up of partners from different ethnic groups are, however, not significantly more apt to enter into a consensual union, against our expectations.

A woman's prior marital experience appears to be a very important determinant of union type. Consensual unions are rare for women's first unions, and much more common among those who previously lived in union and were since divorced, separated or widowed. In sharp contrast, men's prior union experiences have no significant effect on the likelihood of a newly formed union being consensual. This is not an altogether surprising result in the social context of Burkina Faso, where polygynous marriages are common. For the men in our data, most of their earlier contracted relationships are still ongoing, and their new partners were single up until the time of entry into the union under study. In such a situation, it is likely that the women's family would insist on formal marriage, perhaps in part to guarantee her equal status with co-wives.

Our findings also point to a considerable degree of continuity over time marriage/union traditions and behaviors. In the 1960s and 1970s, consensual unions at the start of cohabitation were more common in rural areas. While consensual unions have become more common in recent years, a change that is considerably stronger in cities, the overall degree of the increase has been moderate. As a result, among the set of ongoing unions observed at the time of the survey in 2000 (many of which had been in existence for several years), consensual unions remained somewhat more common in rural areas, although geographic differences were statistically insignificant. ${ }^{11}$ Should time trends continue, consensual unions however should gradually become increasingly concentrated in urban areas. In a study of nearby Togo, Thiriat (1998, ch. 9) similarly documented a higher prevalence of consensual unions in rural areas in 
the past and a faster growth of consensual unions in towns and cities over time, showing that this pattern is not unique to Burkina Faso.

By comparing our results with those of earlier studies by Pool and colleagues on Burkina Faso and Ghana (Coulibaly and Pool, 1975; Pool, 1977; Pool, 1968), based on data from the 1960s, we find further evidence of inertia in the pace of change of marriage/union behaviors. For example, both our study and these earlier ones did not reveal important effects of men's and women's ages on the likelihood of unions being consensual in Burkina Faso. This pattern is in sharp contrast with the situation they documented for Ghana 45 years ago, where consensual unions were heavily concentrated in urban areas and among men and women aged under 25 - groups often thought to be especially open to consensual unions. ${ }^{12}$ Similarly, both this analysis and Pool (1977) found that unions in Burkina Faso are relatively quite stable (unlikely to end in separation or divorce), although we do see evidence of a somewhat higher probability of rupture for women's consensual unions in the 1990s.

Taken together, the findings of this study support the notion that the social significance of consensual unions has been gradually evolving from a phenomenon that was probably grounded in large part in the cultures and customs of the various ethnic groups, and somewhat more common in the less Europeanized rural areas than in the cities, to one that is slowly but increasingly becoming concentrated in urban areas and among those asserting more "modern" attitudes and behaviors. Care, however, should be taken in making this assertion, given the contrasted nature of Burkinabè society and recognizing that our results reflect broad tendencies across heterogeneous subgroups of the population. In-depth cross-setting qualitative research on the social dynamics of union formation and dissolution, examining for instance the perceptions of young men and women on the importance of changing attitudes to marriage versus economic constraints affecting marriage strategies and behaviors, would be a valuable complement to this analysis.

\section{Acknowledgements}

Thanks are due to Thiombiano Bilampoa Gnoumou, Ian Pool, Etienne van de Walle, Nathalie Mondain, Peter Brandon, Neeru Gupta and Youssouf Langani for their comments. Both authors contributed equally to the study. 


\section{End Notes}

1. See articles 231, 234 and 238 of Burkina Faso (1990) for the laws governing civil marriages. At the time of the survey in 2000 , less than $4 \%$ of ongoing unions were civil marriages and most of these had also been sanctified by religious or traditional wedding ceremonies. Religious wedding ceremonies had occurred for $47 \%$ of unions, and traditional ceremonies for almost $60 \%$ (many had both). Roughly $10 \%$ of ongoing unions were consensual, existing in the absence of any type of marriage ceremony.

2. See de Rouville (1987: 207-211) for a description of eloping in traditional Lobi society, Pillon (1994) for nearby northern Togo, and Geismar (1933, cited by Antoine 2007) for the Diolas of Senegal.

3. Ian Pool (personal communication) recalls a common phrase used by Ghanaian women in consensual unions in the mid-1960s, revealing their sense of autonomy: "I drive myself".

4. In French, the Enquête Migration, insertion urbaine et environnement au Burkina Faso. This survey was conducted by the Université de Ouagadougou, the Université de Montréal and the Centre d'Études et de Recherche sur la Population pour le Développement (CERPOD), and was funded by CIDA (Canada) and the Andrew W. Mellon Foundation.

5. Van de Walle and Baker (2004) report that Muslim weddings in Senegal and Mali were often declared early in the process, although we doubt that this would be the case in the socio-cultural context of Burkina.

6. The SMUIE/BF interviewed $100 \%$ of men and women aged $25-64$, and $50 \%$ of those aged 15-25, who were living in the selected households. Many of the ongoing unions at the time of the survey reported by men and women were one and the same - the cases of husbands and wives in the sample; this is generally not the case for past unions. There are also a fair number of ongoing unions reported by just one of the partners. The most important cause of this relates to Sahelian women's tendency to marry at younger ages than men, leading to large age gaps between spouses. Married women were not infrequently under age 25 and half of those were not selected for interviews. This was less often the case for men, as most of those aged 15-25 were single and thus not included in our analysis. In any case, to the extent that men's and women's behaviors differ, the effects of covariates estimated in the regressions will also to differ even for the same set of unions.

7. Kaplan-Meier survival curves for consensual unions, in which marriage is treated as a terminal change in status and union rupture as censored data, show that nearly half of marriages occur during the first year following the start of cohabitation. 
8. Using the same data set, Gnoumou Thiombiano et al. (2007) document a substantial increase in the risk of union dissolution across generations (birth cohorts) in the country, in a study of all cohabiting unions (marriages and consensual unions combined).

Pool (1977) also reports evidence of a high degree of union stability across areas and ethnic groups in Burkina Faso compared to Ghana, using data from a 1969 non-representative random sample of diverse areas of Burkina Faso and a 196566 nationally representative sample of Ghana (Pool, 1968). The most stable unions in Burkina Faso appear to be those that were hardest to break: civil unions and Christian marriages (then mostly Catholic). Second unions of these types were rare (Table 2.5). Second or higher order unions were more often consensual unions, Muslim marriages or traditional marriages, with no clear difference between these three in terms of their implied level of stability. Caution, should be taken in interpreting these statistics, as union type may change over time for given individuals (for example, a woman's first union can be Muslim and her second one consensual), meaning that the frequency of second-order unions of a certain type may not simply reflect differences in union stability.

9. Relative to the pre-1980 period, the odds ratios of a new union being consensual in $1990+$ was 9.9 for all new unions, and 10.4 for longer lasting unions - both significant at the $1 \%$ level.

10. In the other urban areas, comparing $1990+$ to the pre-1980 period, the estimated odds ratio for women was 4.4 for all unions and 8.2 for longer-lasting unions, both of which were significant at the $5 \%$ level. Equivalent odds ratios for the other areas were consistently small $(\leq 1.4)$ and insignificant.

11. $10.0 \%$ of men's ongoing unions were consensual in rural areas, versus $8.3 \%$ in Ouagadougou and $7.8 \%$ in other urban areas. For women, the corresponding statistics were $11.3 \%, 10.0 \%$ and $8.6 \%$, respectively. While consensual unions at the start of cohabitation were more common in urban areas in our data, statistics on ongoing unions are also affected by the likelihood that a union will last up until the time of data collection. Consensual unions are somewhat less stable than marriages, and some of them were formalized by a wedding in the years leading up to 2000 .

12. Pool (1968) reports that between $22 \%$ and $24 \%$ of ongoing unions of urban women aged below 25 in 1965-66 were consensual, versus about $10 \%$ of unions of older urban women. A strong age gradient is also shown for rural areas, where consensual unions were much less common - depending on their age group, only between $1-7 \%$ of their unions were consensual..

Pool (1977) also found that the percentage of ongoing unions that were consensual in Burkina Faso ranged from $5-10 \%$ by area, versus roughly $10 \%$ in our data. Unfortunately, unlike the SMUIE/BF, their data are not nationally 
representative, making it impossible to draw strong conclusions from the small size of this difference.

\section{References}

Adepoju, Aderanti (1997). Family, population and development in Africa, London, England: Zed Books.

Antoine, Philippe (2000a). "Les complexités de la nuptialité: de la précocité des unions féminines à la polygamie masculine en Afrique", in Graziella Casseli, Jacques Vallin et Guillaume Wunsch (éd), Démographie: analyse et synthèse II, les déterminants de la fécondité, Paris, INED, 75-102.

Antoine, Philippe (2000b). "L'approche biographique de la nuptialité: application à l'Afrique", in : Graziella Casseli, Jacques Vallin et Guillaume Wunsch (éd), Démographie: analyse et synthèse II, les déterminants de la fécondité, Paris, INED, p. 51-74.

Antoine, Philippe (2007). "Comportements matrimoniaux au Sénégal à l'interface des traditions, de l'Islam, de la colonisation et de la loi (du XVIIIème au XXème siècle)", presented at the AUF conference on Mémoires et Démographie : Regards Croisés au Sud et au Nord, June 2007.

Antoine, Philippe and Mamadou Djiré (1998). “Un célibat de crise?”, ch. 4 in Philippe Antoine, Dieudonné Ouedraogo and Victor Piché (eds.) Trois Générations de Citadins au Sahel: Trente ans d'histoire sociale à Dakar et à Bamako, Paris: L'Harmattan.

Antoine, Philippe, Mamadou Djiré and Benoit Laplante (1995). "Les déterminants socioéconomiques de la sortie du célibat à Dakar" Population 50(1): 95-118.

Antoine, Philippe and Jeanne Nanitelamio (1990). "Nouveaux statuts féminins et urbanisation en Afrique," Genus 46(3-4): 17-30.

Antoine, Philippe and Jeanne Nanitelamio (1991). "More single women in African cities: Pikine, Abidjan and Brazzaville," Population: an English Selection 3: 149-169.

Attané, Anne (2003). Cérémonies familiales et mutations des rapports sociaux de sexe, d'âge et de génération: Ouahigouya et sa région, Burkina Faso, Doctoral thesis in Social Anthropology and Ethnology, École des Hautes Études en Sciences Sociales. 
Beauchemin, Cris, Sabine Henry and Bruno Schoumaker (2007). "Côte d'Ivoire Burkina Faso (1970-2000): Une étude rétrospective des déterminants individuels et contextuels du retour", Les Migrations Internationales: Observation, Analyse et Perspectives, Paris : Presses Universitaires de France (AIDELF \#12), pp. 157-178.

Bledsoe, Caroline and Gilles Pison (eds.) (1994). Nuptiality in sub-Saharan Africa: Contemporary anthropological and demographic perspectives, Oxford: Clarendon Press.

Boye, Abd-el Kader, K. Hill, S. Issacs and D. Gordis (1991). "Marriage law and practice in Sahel”, Studies in Family Planning, 22(6): 343-349.

Burkina Faso (1990). Code des personnes et de la famille, Ministère de l'action social, Ministère de la Justice, Ouagadougou, 119 p.

Calvès, Anne-Emmanuèlle (2007). "Trop pauvre pour se marier? Crise de l'emploi urbain et entrée en première union des hommes au Burkina Faso", Population 62(2): 339-360.

Calvès, Anne-Emmanuèlle and Dominique Meekers (1999). "The advantages of having many children for women in formal and informal unions in Cameroon", Journal of Comparative Family Studies, 30(4): 617-639.

Calvès, Anne-Emmanuèlle, Jean-François Kobiané and Edith Martel (2007). "Changing Transition to Adulthood in Urban Burkina Faso", Journal of Comparative Family Studies, 38(2): 265-283.

Cooper, Barbara M. (1995). "Women's worth and wedding gift exchange in Maradi, Niger, 1907-89," Journal of African History, 36(1):121-140.

Cordell, Dennis, Joël Gregory and Victor Piché (1998). Hoe and Wage. A Social History of a Circular Migration System in West Africa. Boulder (Colorado): Westview Press, collection "African Modernization and Development Series", 400 p.

Coulibaly, Sidiki and D. Ian Pool (1975). "Un essai d'explication des variations de la fécondité en Haute-Volta et au Ghana", Population et Famille 34(1): 29-54.

Courel, André and D. Ian Pool (1975). "Upper Volta", ch. 35 in J. Caldwell (ed.) Population growth and socioeconomic change in West Africa, New York: Columbia University Press, 736-754.

Dacher, Michèle (1992). "Compensation matrimoniale et dette féminine: les Goin du Burkina Faso", in Relations Genre et Développement: femmes et sociétés, Éditions de l'ORSTOM (Colloques et séminaires): Paris, pp. 57-73.

Dacher, Michèle (1993). "Représentation de la paternité dans une société matrilinéaire: les Goin du Burkina Faso", Journal des Africanistes 63(2): 25-49. 
de Rouville, Cécile (1987). Organisation sociale des lobi: Une société bilinéaire de Haute-Volta, Côte d'Ivoire. Paris: L'Harmattan.

Fièloux, Michèle (1993). Biwanté: récit autobiographique d'un Lobi du Burkina Faso, Paris: Karthala.

Freedman, Deborah, Arland Thornton, Donald Camburn, Duane Alwin, and Linda Young-DeMarco (1988). "The Life History Calendar: A Technique for Collecting Retrospective Data", in C.C. Clogg (ed.) Sociological Methodology 18: 37-68, San Francisco: Jossey-Bass publishers.

Gnoumou Thiombiano, Bilampoa, Thomas LeGrand and Bruno Schoumaker (2007). "Niveaux, tendences et facteurs de divorce au Burkina Faso", paper presented at the UAPS Fifth African Population Conference, Arusha Tanzania, December.

Goody, Jack (1969). Comparative Studies in Kinship, London: Routledge and Kegan Paul.

Hertrich, Véronique (2001). "Nuptialité et rapports de genre en Afrique. Un premier bilan des tendances de l'entrée en union au cours des 40 dernières années", paper presented at the international meetings on Genre, population et développement en Afrique, Abidjan, 16-21 July.

INSD (2000). Analyse des résultats du recensement général de la population et de l'habitat de 1996, volume II, Ouagadougou, 180p.

INSD and Macro International (2000). Enquête Démographique et de Santé du Burkina Faso 1998-99, Calverton Maryland: INSD andMacro International.

INSD and ORC Macro (2004). Enquête démographique et de santé du Burkina Faso 2003, Calverton Maryland: INSD and ORC Macro.

Kaufmann, R.L. and Dominique Meekers (1988). "Caractéristiques et tendances du mariage", in Population et société en Afrique au sud du Sahara, (eds) Tabutin D. pp. 217-248.

Lallemand, Suzanne (1981). "Respect des ancêtres et amour du père chez les Mossi de Haute-Volta", in La Première Fois ou le Roman de Virginité perdue à travers les siècles et les continents. Paris, Ramsay.

Locoh, Thérèse (2000). "Les facteurs de la formation des couples", in Graziella Casseli, Jacques Vallin et Guillaume Wunsch (éd), Démographie: analyse et synthèse II, les déterminants de la fécondité, Paris, INED, pp. 103-142.

Marcoux, Richard, M. Gueye and M.K. Konate. (1995). "La nuptialité: Entrée en union et types de célébration à Bamako", in L'insertion urbaine à Bamako, (eds) Ouédraogo D. and Piché V., 117-144. 
Marcoux, Richard and V. Piché (1998). "Crise, pauvreté et nuptialité à Bamako", in F. Gendreau (ed.) Crise, pauvreté et changements démographiques dans les pays $d u$ sud, Paris: Éditions ESTEM, Paris, pp. 219-235.

Meekers, Dominique (1992). "The Process of Marriage in Africa: A Multiple Indicators Approach”, Population and Development Review 18(1): 61-78.

Mensch, Barbara S., Susheela Singh and John Casterline (2005) "Trends in the Timing of First Marriage among Men and Women in the Developing World", ch. 5 in C. Lloyd et al. (( ds $\square$ The Changing Transitions to Adulthood in Developing Countries: Selected Studies, Washington DC: The National Academies Press, pp. $118-171$.

Mondain, Nathalie (2004). "Être en âge de se marier" et choix du conjoint: continuité et changements des processus matrimoniaux en milieu rural au Sénégal, $\mathrm{PhD}$ dissertation in Demography, Montreal (Canada): Université de Montréal.

NRC (National Research Council and Institute of Medicine) (2005). Growing Up Global: The Changing Transitions to Adulthood in Developing Countries, Report of the Panel on Transitions to Adulthood in Developing Countries (Cynthia Lloyd, ed.) Washington DC: The National Academies Press.

Panel Study of Income Dynamics (2005). "PSID Calendar Methods Study", http://psidonline.isr.umich.edu/data/Documentation/ehc/PSIDcalendarMethodsStu dy.html (assessed 14 Oct. 2005).

Pilon, Marc (1994). "Types of Marriage and Marital Stability: The Case of the MobaGurma of North-Togo", in Bledsoe C. and Pison G. (eds.), Nuptiality in SubSaharan Africa. Contemporary Anthropological and Demographic Perspectives, UIESP, Clarendon Press Oxford, pp. 130-147.

Poirier, Jean, V. Piché, G. Le Jeune, B. Dabiré and H.R. Wane (2001). "Projet d'étude des stratégies de reproduction des populations sahéliennes à partir de l'enquête Dynamique migratoire, insertion urbaine et environnement au Burkina Faso", Cahiers québécois de démographie 30(2): 289-310.

Pool, D. Ian (1968). “Conjugal Patterns in Ghana”, The Canadian Review of Sociology and Anthropology 5(4) : 241-253.

Pool, Janet Sceats (1977). "Conjugal patterns in Upper Volta", ch. 2 in D. Ian Pool and S.P. Coulibaly (eds.) Demographic Transition and Cultural Continuity in the Sahel, Ithaca NY: Cornell University International Population Program, pp. 38-97.

Thiriat, Marie-Paule (1999). "Les unions libres en Afrique subsaharienne", Cahier Québécois de Démographie, 28(1-2): 81-115. 
Thiriat, Marie-Paule (1998). "Faire et défaire les liens du mariage: évolution des pratiques matrimoniales au Togo", Les études du CEPED \#16, Paris, CEPED, $295 \mathrm{p}$.

van de Walle, Etienne (1993). "Recent trends in marriage ages", chapter 4 in K.A. Foote, K.H. Hill and L.G. Martin (eds.) Demographic Change in Sub-Saharan Africa, Washington DC : National Academy Press, pp. 117-152.

van de Walle, Etienne and Kristine R. Baker (2004). "The evolving culture of nuptiality in sub-Saharan Africa", paper presented at the Perspectives on International Family Change Conference, Population Studies Center, University of Michigan, Ann Arbor 3-5 June.

van de Walle, Etienne and Solène Lardoux (2005). “ 'Living with a man': Cohabitation in sub-Saharan Africa", paper presented at the annual meetings of the Population Association of America, Philadelphia, March 31 - April 2.

Wa Karanja, Wambui (1994). "The Phenomenon of 'Outside Wives': Some Reflections on its Possible Influence on Fertility." in C. Bledsoe and G. Pison (eds) Nuptiality in Sub-Saharan Africa, Oxford: Clarendon Press, pp. 194-213. 